\title{
Delo z brezdomnimi in socialno ranljivimi za boljše vključevanje na Območnem združenju Rdečega križa Novo mesto
}

Na Območnem združenju Rdečega križa Novo mesto že od leta 2007 poteka socialno varstveni program »Delo z brezdomnimi in socialno ranljivimi za boljše vključevanje«. Gre za osrednji program, ki se ukvarja s problematiko brezdomstva na območju Dolenjske in Jugovzhodne statistične regije. Vključuje najbolj izključene in pri tem povezuje pomembne vladne in nevladne akterje na tem področju. Pomaga posameznikom in družinam iz osmih občin, ki jih pokriva Območno združenje Rdečega križa Novo mesto. Leta 2021 je postal program javno verificiran, se pravi, da ga bo Ministrstvo za delo, družino, socialne zadeve in enake možnosti sofinanciralo do leta 2027.

V program vključujemo ne samo brezdomne, ampak tudi invalide, samohranilce, odvisnike, tujce, mlade brezposelne, nekdanje zapornike, starejše, Rome in druge socialno izključene, ki nimajo primerne socialne oskrbe. Program vključuje tudi terensko delo za pomoč pri vključevanju starejših in invalidov. Starejše in invalidne, ki živijo sami, obiskujemo na njihovih domovih in tako spoznavamo njihovo življenjsko okolje in pomagamo pri razreševanju socialnih stisk. Glede na potrebe naših uporabnikov smo ugotovili, da ljudem lahko ponudimo še kaj več kot le tradicionalni obliki pomoči Rdečega križa, namreč delitev prehranskih izdelkov in oblačil.

Program uresničuje politiko socialnega varstva države, saj je njegov namen preprečevati nastajanje socialnih težav in svetovanje, socialna krepitev ranljivih skupin in vseh tistih, ki so v socialnih stiskah, in povečanje vključenosti ljudi, ki so zaradi različnih vzrokov izključeni. Program obsega psihosocialno pomoč v obliki svetovanja, informiranja, spodbujanja in razvijanja nekonfliktne komunikacije. Uporabniki lahko preživijo več ur na dan v urejenem prostoru, ki omogoča formalne in neformalne dejavnosti. Za uporabnike organiziramo prostočasne aktivnosti (telovadba, pohodi, ustvarjalne delavnice, tečaj računalništva, utrjevanje plesnih korakov, delavnice socialnih veščin, druženja s prostovoljci, predavanja, delavnice za krepitev in pridobivanje socialnih izkušenj in znanj). Zaradi epidemije izvajamo aktivnosti v skladu z ukrepi vlade in navodili Nacionalnega inštituta za javno zdravje.

Uporabnikom zagotavljamo dnevni topli obrok, donirano hrano, pranje in urejanje oblačil ter možnost vzdrževanja osnovne higiene. Omogočamo premostitvene materialne pomoči $\mathrm{v}$ obliki preskrbe $\mathrm{s}$ hrano in finančnimi pomočmi za najnujnejše življenjske stroške. Program obsega tudi pomoč pri urejanju postopkov pred deložacijami in pomoč v primeru deložacij. V tem primeru zagotavljamo tudi začasno pomoč z nastanitvijo v garsonjeri humanitarnega centra. 
Kot strokovna vodja ugotavljam, da je vse več uporabnikov, ki potrebujejo obiske na domu, druženje in pomoč pri vsakodnevnih opravilih, saj tega javne službe ne morejo zagotavljati v zadostni meri. Zato uporabnike pogosto obiskujemo na domovih. V skupino ali individualno vključujemo prostovoljce, ki organizirajo kakovostnejše preživljanje prostega časa in omogočajo širitev socialne mreže našim uporabnikom. Prostovoljci pomembno povečujejo kakovost dela z brezdomnimi in drugimi socialno izključenimi uporabniki $\mathrm{v}$ programu. Z njimi se redno družijo, pogovarjajo, spoznavajo njihov življenjski svet, ugotavljajo njihove potrebe, želje in interes ter sodelujejo na delavnicah in predavanjih, kjer ponujajo svoje znanje in spretnosti. Velikokrat so tako uporabniki bolj motivirani, saj ohranjajo odnos s prostovoljci, ki jim veliko pomeni. Večji delež uporabnikov prostovoljci obiskujejo tudi na domovih in jim pomagajo pri preskrbi s hrano in pri manjših hišnih opravilih. Pomagajo pri urejanju bivalnih razmer in učenju gospodinjskih spretnosti. S prostovoljci redno opravljamo pogovore; povedo, kakšno podporo potrebujejo od nas zaposlenih in kje vidijo dodatne možnosti za razširitev programa.

Med izvajanjem programa uporabljamo različne metode socialnega dela. Delo z uporabniki poteka individualno na sedežu, lahko pa tudi pri uporabniku na domu ali skupinsko na sedežu Območnega združenja Rdečega križa. Ob vključitvi v program izhajamo iz potreb uporabnika in njegove ocene situacije ter njegove ocene potreb po storitvah, s katerimi si bo izboljševal kakovost življenja - to z vsakim uporabnikom opredelimo v individualnem načrtu. Ob tem spodbujamo k participaciji, ustvarjamo odnos, zagotavljamo podporo in omogočamo vključitev v dejavnosti, ki jih organiziramo za podporo uporabnikom.

$\mathrm{V}$ procesu individualnega načrtovanja storitev in uresničevanja ciljev upoštevamo uporabnikove želje, da ohranja vpliv na proces zagotavljanja socialnovarstvene storitve, si izboljšuje kakovost življenja $\mathrm{z}$ aktivnim sodelovanjem in da je lastnik individualnega načrta, ki ga lahko kadarkoli spremeni.

Uporabnik sooblikuje program že s svojim problemom, s katerim vstopi $\mathrm{v}$ program, to pa zahteva individualiziran pristop glede intenzivnosti, obsega, vsebine in dinamike iskanja boljših izhodov. Na podlagi tega program usmerjamo v svetovanje, udeležbo na prostočasnih dejavnostih, pomoč. Uporabniki sodelujejo pri načrtovanju in izvedbi programa s svojimi predlogi, kritikami, idejami - upoštevamo jih in vključujemo v program. Sami odločajo o trajanju vključenosti v program, imajo vpliv na izbiro terminov in trajanje programa, program lahko zapustijo in se spet vrnejo.

Osnovne metode dela so: prvi pogovor, individualna psihosocialna svetovanja in pogovori z uporabniki. Skupaj z uporabnikom določimo osebne cilje in jih skupaj zapišemo v individualiziranem programu. Sledijo podpora uporabniku, pomoč in krepitev moči za dosego ciljev, spremljanje načrta, eventualno sprememba ciljev, določanje dodatnih aktivnosti za dosego ciljev in evalvacija doseženih ciljev. Uporabljamo tudi osebno pomoč, ki obsega svetovanje, urejanje in vodenje z namenom, da bi posamezniku omogočili razvijanje, dopolnjevanje, ohranjanje in izboljšanje socialnih zmožnosti. 
Upoštevamo osnovna načela za izvajanje sistema socialnega varstva in zagotavljanje človekovega dostojanstva, socialne pravičnosti, spodbujanja prostovoljstva in solidarnosti, krepitev moči skupnosti z namenom preprečevanja in blaženja socialnih stisk, medgeneracijske povezanosti, enake dostopnosti, proste izbire in individualizirane obravnave.

Uporabljamo tudi metodo socialnega dela, usmerjenega $\mathrm{v}$ nalogo.

Metode izvajamo z različnimi strokovnimi ravnanji, oblikami dela in aktivnostmi, terenskim delom in raziskovanjem življenjskega sveta uporabnikov. Skupnostno delo obsega izboljšanje prepoznavnosti programa. Da bi ozaveščali o aktivnostih programa, večkrat na leto predstavljamo problematiko brezdomnih in socialno šibkih javnosti. 0 tem pišemo članke in jih objavljamo v lokalnih časopisih.

Sestavni del programa so vnaprej načrtovani tedenski sestanki vključenih $\mathrm{v}$ program, mesečna supervizija, timski sestanki in povezovanje $\mathrm{z}$ drugimi institucijami.

Učinkovitost programa ugotavljamo tako z vidika uporabnika kot z vidika izvajalca, saj tudi vnaprej načrtovane cilje na začetku procesa določita oba. Po končanem procesu izvajalec preveri doseganje ciljev pri sebi in pri uporabniku. Podrobneje je to zapisano $\mathrm{v}$ individualiziranem programu uporabnika in $\mathrm{v}$ evalvacijskih poročilih posameznih vključenih uporabnikov. Evalvacija nam daje smernice za nadaljnje delo.

Program je v lokalnem okolju dobro sprejet in lahko se pohvalimo z izjemno dobrim sodelovanjem z občinami, društvi in drugimi institucijami v lokalnem okolju. Najpogosteje sodelujemo s Centrom za socialno delo Dolenjske in Bele Krajine, Enota Novo mesto, z lokalnimi društvi, nevladnimi organizacijami in patronažnimi službami Zdravstvenega doma Novo mesto. Strokovne delavke na centru redno obveščamo o naših uporabnikih in njihovih potrebah. Medsebojno si izmenjujemo informacije za boljšo oskrbo uporabnikov.

Povezujemo se tudi z vsemi izvajalci na področju brezdomstva. Sodelujemo v koordinacijski skupini na področju brezdomstva v Sloveniji. Smo aktivni člani društva Brezdomni do ključa.

Število brezdomcev se je zaradi epidemije povečalo oziroma ga je epidemija samo še bolj razkrila. Imamo več ljudi, ki živijo v tako slabih stanovanjskih razmerah, da niso primerne za življenje (brez vode, elektrike, objekti se podirajo). Ker na območju Jugovzhodne statistične regije ni zavetišča za brezdomne, imamo težavo, kam namestiti osebe, ki so brez bivališča. Skupaj s Centrom za socialno delo Novo mesto in občinami v širši Jugovzhodni statistični regiji si intenzivno prizadevamo, da bi prišli tudi do programa zavetišča za brezdomne, ker ga nimamo, zato opozarjamo lokalne skupnosti, da bi se zavedale potreb in omogočile prostor za namestitev ljudi, ki živijo brez doma.

\section{Maja Gorenc Šulc}


